Portland State University

PDXScholar

Civil and Environmental Engineering Faculty

Publications and Presentations

$11-2013$

\title{
Nineteenth Century North American and Pacific Tidal Data: Lost or Just Forgotten?
}

Stefan A. Talke

Portland State University, talke@pdx.edu

David A. Jay

Portland State University, djay@pdx.edu

Follow this and additional works at: https://pdxscholar.library.pdx.edu/cengin_fac

Part of the Ocean Engineering Commons, and the Oceanography Commons

Let us know how access to this document benefits you.

\section{Citation Details}

Talke, Stefan A., and David A. Jay. "Nineteenth Century North American and Pacific Tidal Data: Lost or Just Forgotten?." Journal of Coastal Research (2013).

This Article is brought to you for free and open access. It has been accepted for inclusion in Civil and Environmental Engineering Faculty Publications and Presentations by an authorized administrator of PDXScholar. Please contact us if we can make this document more accessible: pdxscholar@pdx.edu. 


\title{
Nineteenth Century North American and Pacific Tidal Data: Lost or Just Forgotten?
}

\author{
Stefan A. Talke and David A. Jay \\ Portland State University \\ Department of Civil and Environmental Engineering \\ Portland, OR 97207, U.S.A. \\ s.a.talke@pdx.edu
}

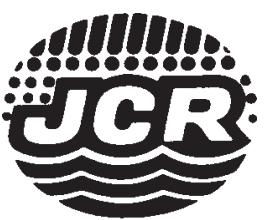

www.JCRonline.org

\begin{abstract}
Talke, S.A. and Jay, D.A., 2013. Nineteenth century North American and Pacific tidal data: lost or just forgotten? Journal of Coastal Research, 29(6A), 118-127. Coconut Creek (Florida), ISSN 0749-0208.

Tide data are the oldest and longest oceanographic records and comprise one of the few tools for understanding, quantifying, and separating century-scale human and climate impacts on the coastal zone. Our archival research indicates that continuous measurements of tides began in 1844 in the western Atlantic, 1853 in the Eastern Pacific, and 1858 in the Western Pacific. At least 50 multiyear tide series existed by the year 1900. With few exceptions, however, these 19th and early 20th century measurements have not been analyzed in more than a century and have been forgotten and neglected by the scientific community. This article describes historical tide measurements in the Pacific Ocean and North America, their current status, and ongoing efforts to recover the data. Possible uses of the data include assessing trends in sea level, tidal properties, and river flow, and reanalyzing extreme events such as historical storms and floods. More than 600 years of station data are confirmed to still exist in paper form, out of approximately 1900 years total.
\end{abstract}

ADDITIONAL INDEX WORDS: Tide data, mean sea level, tidal dynamics, historical reanalysis, extreme events, hydrological change, data recovery.

\section{INTRODUCTION}

The few available 19th and early 20th century tidal data sets from the Pacific Ocean and North America are most often used to help reconstruct historic mean sea-level (MSL) and estimate MSL acceleration (Church and White, 2011; Hannah, 1990; Jevrejeva et al., 2006; Maul and Martin, 1993). Historic tide data, however, can also help determine trends in tidal range and storminess (Bromirski, Flick, and Cayan, 2003), reconstruct extreme events and storm surge (Woodworth and Blackman, 2002), characterize changes in estuarine processes (Amin, 1983), assess geologic uplift/subsidence (Wood and Elliot, 1979), describe climate cycles such as El Nino/La Nina (Komar, Allen, and Ruggerio 2011), and hindcast historical river flow (Jay and Kukulka, 2003). Extreme water levels depend on changing MSL but also on tidal range and storm impacts, all of which have been increasing in the Eastern Pacific for more than a century (Bromirski, Flick, and Cayan, 2003; Jay, 2009). Long-term changes in tidal constituents worldwide (Jay, 2009; Woodworth 2010) reflect altered oceanic conditions (Colosi and Munk, 2006) but also occur because of local channel modifications, channel deepening, and altered hydraulic roughness (Amin, 1983). Extreme cases are found on the North Sea coast: for example, tidal range in the Ems estuary on the German/Dutch border has increased fivefold

DOI: 10.2112 / JCOASTRES-D-12-00181.1 received 8 September 2012 , accepted in revision 25 January 2013; corrected proofs received 13 March 2013.

Published Pre-print online 2 April 2013.

(C) Coastal Education \& Research Foundation 2013 because of increasing North Sea tidal range, installation of a weir in 1899 (river $\mathrm{km}$-12.7), and channel deepening/ streamlining since 1960 (Figure 1a). A direct consequence of the changed tidal dynamics (Chernetsky, Schuttelaars, and Talke, 2010) is greater sediment trapping and summer time hypoxia (Talke, de Swart, and de Jonge, 2009).

Long tidal records allow analyses of site-specific tidal dynamics, river flow, and coastal upwelling, even if they are not tied to modern benchmarks. This is particularly important when no other hydrographic records exist. For example, San Francisco Bay river flow was hindcast between 1858 and 1930 (Figure 1b), using the observation that increasing river flow alters tidal amplitudes and phases (Kukulka and Jay, 2003). The results suggest a $30 \%$ decrease in annual flow since the 19 th century and a shift from a snowmelt influenced system to a primarily rain-driven system (Moftakhari et al., 2013). This analysis also suggests that the great 1862 flood was $\sim 25-30 \%$ larger than any other flood since 1858.

Determining accurate tidal and MSL trends requires records over a time period greater than sources of variability such as the nodal cycle and Pacific Decadal Oscillation (Woodworth, 2010). In addition, estimates of MSL acceleration are often dependent on the start date (Rahmstorf and Vermeer, 2011), and the uneven spatial distribution of long records complicates estimates of MSL rise and acceleration (Jevrejeva et al., 2006). Hence, one strategy to address the recent controversy regarding MSL acceleration (e.g. Houston and Dean, 2011; Rahmstorf and Vermeer, 2011; Watson, 2011) is to increase the number, length, and spatial distribution of historic records. All 


\section{(a) Ems Estuary Tides}

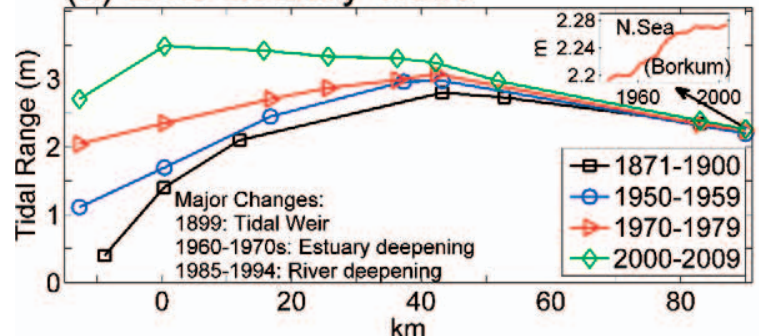

(b) SF Bay inflow

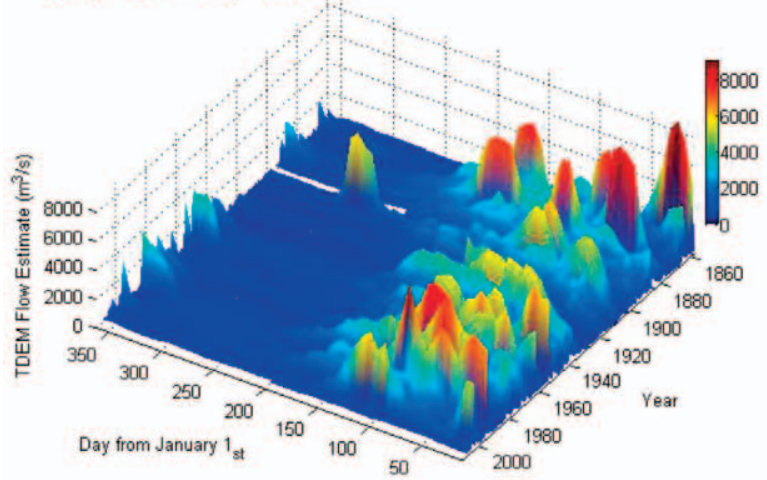

Charracteristie Curves

of the Astoria self registering gauge record,

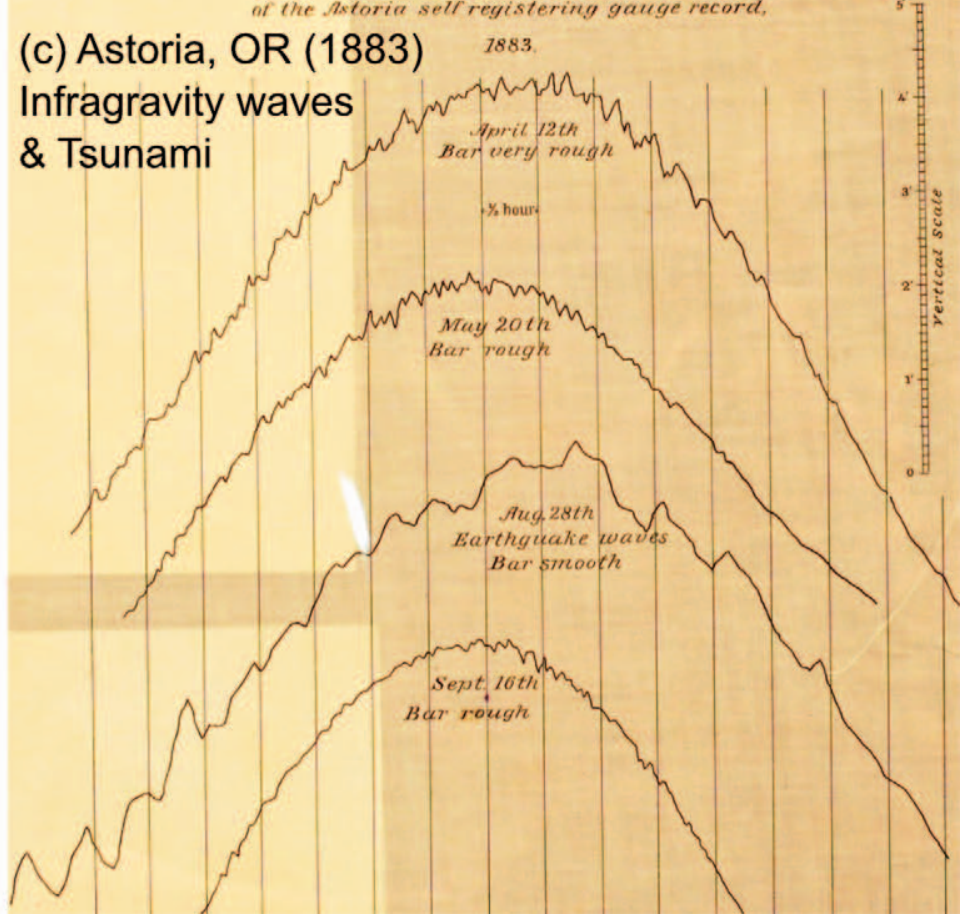

Figure 1. (a) Change in Ems estuary tidal range (pre-1900 from Keller [1901]). (b) Inflow into San Francisco Bay from 1858-1986 using tide data (Moftakhari et al., 2013). (c) Long-period waves (5-30 minutes) and the Krakatoa tsunami measured in Astoria, Oregon (Powell, 1884). Each vertical line denotes half an hour. (Color for this figure is available in the online version of this paper.)

of these examples emphasize the importance and benefits of historic tidal data recovery.

\section{RESULTS OF ARCHIVAL RESEARCH}

Memory of most pre-1900 tide records has largely disappeared from the modern scientific literature, despite their potential uses. Data from 33 mid-19th century U.S. gauges, some of which were multiyear series, were last analyzed by Bache (1855). Nineteenth-century MSL in Boston, Massachusetts, from 1847-77 and 1897-1902 was last analyzed by Freeman (1903). Similarly, 19th century Canadian data from as early as 1850 (Halifax) were last referenced by Proudman (1920). On the U.S. west coast, 19th century hourly data for Astoria and San Diego were last referenced (but not used) by Roden (1966), while Wood and Elliot (1979) last analyzed annually averaged 19th century San Diego MSL to estimate vertical crustal movements. Matthäus (1972) last mentioned Australian data from as early as 1858. The only exceptions to this neglect are short segments of marigrams (the original pencil trace on paper produced by a tide gauge), which have been used to reconstruct past tsunamis (e.g. Lander, Lockridge, and Kozuch, 1993). Figure 1c shows a trace from the 1883 Krakatoa tsunami, as measured in Astoria, Oregon. Other nontidal, infragravity fluctuations evident in Figure 1c were caused by elevated coastal winds and ocean waves, as described in Powell (1884), and were used by local mariners to assess wave conditions at the Columbia River bar.

\section{Pacific Ocean Measurements}

The history of Pacific Ocean tide measurements before 1910 is reconstructed in Table 1 and Table 2 from historic literature and our research in U.S. and Canadian archives. U.S. Coastal Survey annual reports (1854-1876) indicate that self-registering tide gauges were installed in 1853 in Astoria, San Diego, and San Francisco. Continuous measurements began before 1900 in Australia (1858), New Zealand (1883), Japan (1891), and Canada (1893). The French measured tides in Panama (1881-88), and Americans began tidal measurements in Hawaii (1877) and the Philippines (1901). Tide gauges were used for military purposes (Smith, 1997), surveying, and tide predictions, and data were analyzed using specialized machines in Washington, D.C. and England. Station information shown in Table 1 and Table 2 and descriptions of tidal constituents, MSL, data quality, and other observations were found in Ellery (1880), Wharton (1888), Darwin (1891), Russell (1890-1903, annually), Wright (1902), Dawson (1907), Hirayama (1911), Proudman (1920), USACE (1881-1915), IHR (1932), Matthäus (1972), and historic U.S. Coast and Geodetic Survey (USC\&GS) (1877-1910) annual reports and USC\&GS tide tables.

Of the 27 pre- 1900 records listed in Table 1 and Table 2 , only two are available pre-1899 as digitized hourly data (San 
Table 1. List of present-day tide gauges in the Eastern Pacific that collected data for four or more years before 1910. Confirmed years have been located in U.S. and Canadian archives by authors.

\begin{tabular}{|c|c|c|c|c|c|}
\hline Location & Start Date & $\begin{array}{l}\text { Confirmed Years Extant } \\
\text { in Undigitized Form }\end{array}$ & $\begin{array}{c}\text { Years } \\
\text { Unaccounted }\end{array}$ & $\begin{array}{c}\text { Currently Digitized } \\
\text { Hourly }\end{array}$ & $\begin{array}{l}\text { Total Years } \\
\text { Undigitized }\end{array}$ \\
\hline San Francisco, $\mathrm{CA}^{1}$ & 1853 & 1853 & - & 1854-pr (present) & $\overline{1}$ \\
\hline San Diego, $\mathrm{CA}^{2}$ & 1853 & $1853-72^{\mathrm{R}}$ & - & $1906-\mathrm{pr}$ & 19 \\
\hline Astoria, $\mathrm{OR}^{3}$ & 1853 & $1853-76^{\mathrm{R}}$ & 1883-1907 & 1925-pr & 45 \\
\hline Port Townsend, WA ${ }^{4}$ & 1855 & $1855,{ }^{\mathrm{R}} 1873-77,{ }^{\mathrm{R}} 1933-35,1941,1952$ & - & $1966,1972-\mathrm{pr}$ & 10 \\
\hline Seattle, $\mathrm{WA}^{5}$ & 1891 & $1891-92$ & - & 1899-pr & 1 \\
\hline Kodiak, $\mathrm{AK}^{6}$ & 1880 & $1880-91,{ }^{\mathrm{R}} 1906-09,{ }^{\mathrm{R}} 1918-20,1932-39,1949-74$ & - & $1975-\mathrm{pr}$ & 48 \\
\hline Honolulu, $\mathrm{HI}^{7}$ & 1877 & $1883-84,1892-99,1901-04$ & 1900 & 1877-82, with gaps; $1905-$ pr & 13 \\
\hline Victoria, $\mathrm{BC}^{8}$ & 1893 & $1905-08$ & 1893-1904 & $1909-\mathrm{pr}$ & 16 \\
\hline Pt Atkinson, BC & 1897 & $1920,1922-40,1959-60^{\text {IOSA }}$ & $\begin{array}{l}\text { 1897-1906, } \\
\text { 1908, 1910-13, } \\
\text { 1941-43, 1945-46 }\end{array}$ & $\begin{array}{l}1914-19,1921-22, \\
1927,1933,1939, \\
1944,1947-58,1961-p r\end{array}$ & 38 \\
\hline Vancouver, BC & 1901 & $1901,1905-08,1924-39,1940,1942^{\text {IOSA }}$ & $1902-04$ & $1909-23,1941,1943-\mathrm{pr}$ & 25 \\
\hline Tofino, BC & 1905 & $1905-08,1921-39,1942,1944,1946,1948^{\text {IOSA }}$ & - & 1909-pr, with gaps & 27 \\
\hline Prince Rupert, BC & 1906 & $1906-08,1920,1922,1925-26,1928-38,1942^{\mathrm{IOSA}}$ & - & 1909-pr, with gaps & 19 \\
\hline Isle de Naos, ${ }^{9} \mathrm{PA}$ & 1881 & & $1881-88$ & Nearby Balboa, 1907-pr & 8 \\
\hline Total & & $\sim 200$ years confirmed & $\sim 68$ years & & $\sim 270$ years \\
\hline
\end{tabular}

Abbreviations: $\mathrm{R}=$ recovered in paper form by authors; IOSA = data available at Institute of Ocean Sciences (IOS) archives, Sidney, British Columbia (BC).

Notes 1-9 are described in the supplementary material. References consulted for this table include Roden (1966), Dawson (1907), and IHR (1932).

Francisco and Honolulu) and only two (San Francisco and Sydney) are used to evaluate 19th century MSL in the Pacific (e.g. Church and White, 2011). A subset of the 20th century data has been digitized and made available by government agencies, PSMSL (Permanent Service for Mean Sea Level) and GLOSS/IOC (the Global Sea Level Observing System/ Intergovernmental Oceanographic Commission (Caldwell, 2003; Levitus et al., 2005); however, many record segments remain undigitized, particularly between 1850 and 1950. Table 1 and Table 2 document 200 years and 93 years, respectively, of extant, undigitized records and a combined 1273 station years of unaccounted data (likely a mixture of extant data, lost data, and recording gaps). Many marigram and tabulated records are stored by the U.S. National Archives and by the National Oceanographic and Atmospheric Administration (NOAA; Silver Spring, MD). Other records are stored in Australian,

Table 2. List of present-day tide gauges in (or near) the Western Pacific region that collected data for four or more years before 1910.

\begin{tabular}{|c|c|c|c|c|c|}
\hline Location & Start Date & $\begin{array}{l}\text { Confirmed Years Extant } \\
\text { in Undigitized Form }\end{array}$ & Years Unaccounted & $\begin{array}{c}\text { Currently Digitized } \\
\text { Hourly }\end{array}$ & $\begin{array}{l}\text { Total Years } \\
\text { Undigitized }\end{array}$ \\
\hline Fort Denison $^{1}$ (Sydney), NSW & 1867 & 1905-13 NSWA, 1910 NARA-CP ${ }^{R}$ & $1867-1904$ & 1914-pr (present) & 47 \\
\hline Newcastle, ${ }^{2}$ NSW & 1870 & 1907-09 NSWA & $1870-1906,1910-24$ & $1925-\mathrm{pr}$ & 55 \\
\hline Yamba, ${ }^{5 *}$ NSW (Clarence River) & 1900 & 1946-63 NSWA & $1900-45,1964-83$ & $1984-\mathrm{pr}$ & 84 \\
\hline Williamstown, ${ }^{3}$ VIC & 1858 & & 1858-1965 & 1966-pr & 108 \\
\hline Hobart, ${ }^{* 4}$ TAS & 1889 & & $1889-1959,1961$ & $1960-\mathrm{pr}$ & 72 \\
\hline Ballina, ${ }^{5}$ NSW & 1897 & 1946-63 NSWA & $\begin{array}{l}1897-1945 \\
1964-85\end{array}$ & $1986-$ pr & 89 \\
\hline Brisbane, ${ }^{* 6} \mathrm{QLD}$ & 1865 & & 1865-1956 & 1957-pr & 92 \\
\hline Cairns, ${ }^{* 7}$ QLD & ca. 1890 & & $1890-1959,1961-65$ & $\begin{array}{l}1960,1966-76, \\
1978,1982-\text { pr }\end{array}$ & 75 \\
\hline Wellington, ${ }^{8} \mathrm{NZ} * *$ & 1887 & 1891-94 (NARA-KC) $)^{\mathrm{R}}$ & $1887-90,1895-1943$ & 1944-pr & 57 \\
\hline Lyttleton, ${ }^{9} \mathrm{NZ} * *$ & ca. 1883 & **1886-1910 in NZNA (unconfirmed) & $1883-1923$ & 1924-pr & 41 \\
\hline Dunedin, $\mathrm{NZ}^{* *}$ & ca. 1883 & 1898 (NARA-KC) & $1883-1897$ & 1899-pr, with gaps & 15 \\
\hline Auckland, NZ & 1899 & & 1899-1902 & $1903-\mathrm{pr}$ & 4 \\
\hline Westport, ${ }^{10} \mathrm{NZ}^{*}$ & ca. 1901 & & $1901-81$ & $1982-\mathrm{pr}$ & 81 \\
\hline Ayukawa, ${ }^{11} \mathrm{JP} * * *$ & 1891 & & 1891-1961 & $1962-\mathrm{pr}$ & 71 \\
\hline Hanasaki, JP*** & 1895 & & 1895-1963 & 1964-pr & 69 \\
\hline Yokohama, JP*** & 1899 & & 1899-1960 & 1961-96 & 62 \\
\hline Aburatsubo, JP*** & 1893 & & 1894-1932 & 1933-pr & 39 \\
\hline Kushimoto, JP*** & 1892 & & 1892-1960 & 1961-pr & 69 \\
\hline Hosojima, ${ }^{12}$ JP*** & 1892 & & 1892-1932 & 1933-pr & 41 \\
\hline Keelung, ${ }^{13} \mathrm{TW}^{* * *}$ & 1904 & & $1904-79$ & $1980-\mathrm{pr}$ & 76 \\
\hline Manila, $\mathrm{PH}$ & 1901 & 1901-40 (NOAA/NARA-KC) & $1941-47$ & 1948-pr & 48 \\
\hline Total & & $\sim 93$ years confirmed & $\sim 1202$ years & & $\sim 1295$ years \\
\hline
\end{tabular}

Abbreviations: *Not known if gauge record is uninterrupted. **Unconfirmed old tide data available in NZ national archives. ***84 pre-1940 tide stations are microfiched by the Japan (JP) Oceanographic Data Center and might include these data. NSWA = New South Wales archives; NARA-CP = U.S. National Archive, in College Park, MD; NARA-KC= U.S. National Archive in Kansas City, MO; R= recovered (photographed) by authors. For notes \#1-13, see supplementary material. References consulted for this table include AAAS (1913), Chapman (1938), Hannah (1990), Hirayama (1911), Proudman (1920), Richardson (1901), Russell (1885), Russell (1890-1903), USHO (1920), Wharton (1888), Wilson (1938), and Wright (1902). 
Table 3. Tide gauges off the East Coast of North America with at least 4 years of pre-1910 data. Confirmed data has been located (by authors) at U.S. and Canadian archives.

\begin{tabular}{|c|c|c|c|c|c|}
\hline Station & Start Date & $\begin{array}{l}\text { Confirmed Years Extant } \\
\text { in Undigitized Form }\end{array}$ & $\begin{array}{c}\text { Years } \\
\text { Unaccounted }\end{array}$ & $\begin{array}{c}\text { MSL Data } \\
\text { (PSMSL, NOAA) }\end{array}$ & $\begin{array}{c}\text { Hourly Data } \\
\text { Available }\end{array}$ \\
\hline St. John, NB & 1896 & $\begin{array}{c}1899-1904,1918,1922 \\
1925,1928,1935-38\end{array}$ & - & $\begin{array}{l}\text { 1896-pr (present), } \\
\text { with gaps }\end{array}$ & $\begin{array}{l}\text { 1896-pr, } \\
\text { with gaps }\end{array}$ \\
\hline Halifax, NS & 1851 & $1896,1898-1920$ & $\begin{array}{l}1851-52 \\
1861-62\end{array}$ & $1897,1921-$ pr & $1897,1921-\mathrm{pr}$ \\
\hline Eastport, ME & 1860 & $1860-64,1918$ & - & 1930-pr & 1930-pr \\
\hline Pulpit Bay, ME & 1870 & $1870-88$ & - & $1983-85$ & \\
\hline Portland, ME & 1852 & $1852-53,1864-66,1910-11$ & - & 1912-pr & $1912-\mathrm{pr}$ \\
\hline Boston, MA & 1847 & $1847-77,1903-11$ & $\begin{array}{r}1897-1902,^{\mathrm{D}} \\
1912-28^{\mathrm{i}, \mathrm{M}}\end{array}$ & $1921-\mathrm{pr}$ & $1921-\mathrm{pr}$ \\
\hline Newport, RI & 1844 & $1844-46,1892-95$ & - & 1930-pr & 1930-pr \\
\hline Providence, RI & 1872 & $1872-92$ & $1893-1902^{\mathrm{M}}$ & 1938-pr & 1979-pr \\
\hline Willets Point, NY & 1885 & $1885,1890-96$ & - & $\begin{array}{l}\text { 1930-2000, } \\
\text { Kings Pt. 1998-pr }\end{array}$ & $1957-2000$ \\
\hline New York, NY & 1844 & $1844-1879,1885$ & $\begin{array}{l}1886-1920^{\mathrm{M}} \\
\quad(\text { Port Docks) }\end{array}$ & $1856-78,1893-\mathrm{pr}$ & 1920-pr \\
\hline Brooklyn, NY & 1855 & $1855-65$ & - & - & - \\
\hline Sandy Hook, NJ & 1844 & $\begin{array}{l}1844-46,1855-58 \\
1872-93,1907-09\end{array}$ & - & $1910-$ pr & 1910-pr \\
\hline Reedy Island, DE & 1896 & 1896-1903 & - & $1956-65,1973-\mathrm{pr}$ & 1996-pr \\
\hline Baltimore, $\mathrm{MD}^{1}$ & 1845 & $\begin{array}{l}1845,{ }^{\mathrm{i}} 1853-54,{ }^{\mathrm{i}} 1855-56,1863,{ }^{\mathrm{i}} \\
\quad 1866,{ }^{\mathrm{i}} 1876,{ }^{\mathrm{i}} 1886,{ }^{\mathrm{i}} 1898,{ }^{\mathrm{i}} 1899^{\mathrm{i}}\end{array}$ & & $1902-\mathrm{pr}$ & $1902-$ pr \\
\hline Annapolis, MD & 1844 & $\begin{array}{l}\text { 1844-47, 1853, 1870, } 1888 \\
\quad \text { (intermittent surveys) }\end{array}$ & & 1928-pr & 1928-pr \\
\hline Washington, D.C. & 1852 & $1852,1858-60,1891-1902,1925$ & - & 1931-pr & 1931-pr \\
\hline Old Point Comfort, $\mathrm{VA}^{2}$ & 1844 & $\begin{array}{l}1844-79,1906,1907 \\
1909-10,1918-19\end{array}$ & - & $1927-\mathrm{pr}^{\mathrm{H}}$ & 1927-pr \\
\hline Wilmington, NC & 1882 & $1882,1887,1890-91,1908-11$ & & 1930-pr & 1930-pr \\
\hline Charleston, $\mathrm{SC}^{3}$ & 1850 & $1850-61,1882-1908,1910,1913$ & - & 1856 & 1921-pr \\
\hline Fort Pulaski/Tybee Island, GA & 1851 & $\begin{array}{l}1851-52,1889-92 \\
\quad\left(1854,{ }^{\mathrm{i}} 1866,{ }^{\mathrm{i}} 1897^{\mathrm{i}}\right)\end{array}$ & $\begin{array}{l}1894-95,{ }^{\mathrm{C}} 1903-05,{ }^{\mathrm{C}} \\
1911-20^{\mathrm{C}}\end{array}$ & 1935-pr & $1935-\mathrm{pr}$ \\
\hline Fernandina, FL (Ft. Clinch) & 1855 & $1855-61,1869-71,{ }^{\mathrm{i}} 1878-79$ & $1890-91^{\mathrm{C}}$ & 1897-1924, 1938-pr & 1897-1924 1938-pr \\
\hline Key West ${ }^{4}$ & 1847 & $1847,{ }^{\mathrm{i}} 1850-52,1857-59,1903$ & - & $1913-$ pr & 1913-pr \\
\hline Cedar Keys, FL & 1858 & $1858-60,1892-93$ & & $1914-25,1938-\mathrm{pr}$ & 1997-pr \\
\hline Total to recover/digitize & & $\sim 330-340$ years & as much as $\sim 95$ years & & \\
\hline
\end{tabular}

Notes: I = intermittent survey; C = U.S. Army Corps of Engineers Measurement; D = Deer Island, MA; H=Hampton Roads, VA; M= Municipal (City) gauge.

(1) Also Fort Carroll, Fort McHenry; (2) also known as Fort Monroe; (3) Fort Sumter, Castle Pinckney; (4) see Maul and Martin (1993).

Canadian, Japanese, and New Zealand archives (Table 1 and Table 2).

\section{Western Atlantic Measurements}

Tidal measurements during the 19th century were also widespread between Florida and New Brunswick on the east coast of North America (Table 3). Continuous tidal measurements began in the 1840 s and 1850 s, and many multidecade records are extant as tabulated (but not digitized) data or as analog marigrams from locations such as Boston, Sandy Hook, Old Point Comfort, and Charleston. Altogether, more than 330 years of extant, undigitized pre-1920 data have been located for the 23 stations in Table 2 . By contrast, only 84 years of pre1920 hourly data is currently digitized, with the earliest hourly data from 1896-97 (Fernandina; St. John, New Brunswick; and Halifax). Similarly, MSL data are available at PSMSL for only one station pre-1897 (New York, 1856-78, 1893-present). Our research indicates that nearly 100 years of tide data are unaccounted for, primarily measurements by city governments; for example, the Port Docks authority in New York, New York, measured tides continuously at Pier A from 1886 to at least 1920 (Schureman, 1934). As in the Pacific, both longterm trends (tidal, sea level) and information regarding extreme events (extreme water level in Boston in 1851, the 1893 New York hurricane, and the 1893 and 1894 hurricane surge in Charleston) are contained within the undigitized data.

\section{Description of Extant Records}

The type of analog records available parallels the historical development of tide predictions and tidal science (Reidy, 2008). Bathymetric surveys by the U.S. Coastal Survey required tidal elevations. These short tidal series ( $<6$ months) from various U.S. coastal locations and colonies are available from 18351950 at the U.S. National Archives. Early tidal analysis and tide predictions required the times and heights of high and low water, preferably from long ( $>1$ year) data sets. Therefore, multiyear, hand-measured time series from the $1840 \mathrm{~s}$ and 1850s typically include 1-2 hours of data around the daily extrema in 10-15 minute increments (Figure 2).

During the early to mid-1850s, the U.S. Coastal Survey began using the Saxton automatic tide gauge, which produced a continuous pencil trace on a $\sim 20 \mathrm{~m}$ long scroll on a monthly basis (Figures 3 and 4). In the U.S., these marigram data were reduced to tabulations of high and low water and analyzed by subsequent first and second reductions (see supplementary material). Because the marigram traces contained nontidal 


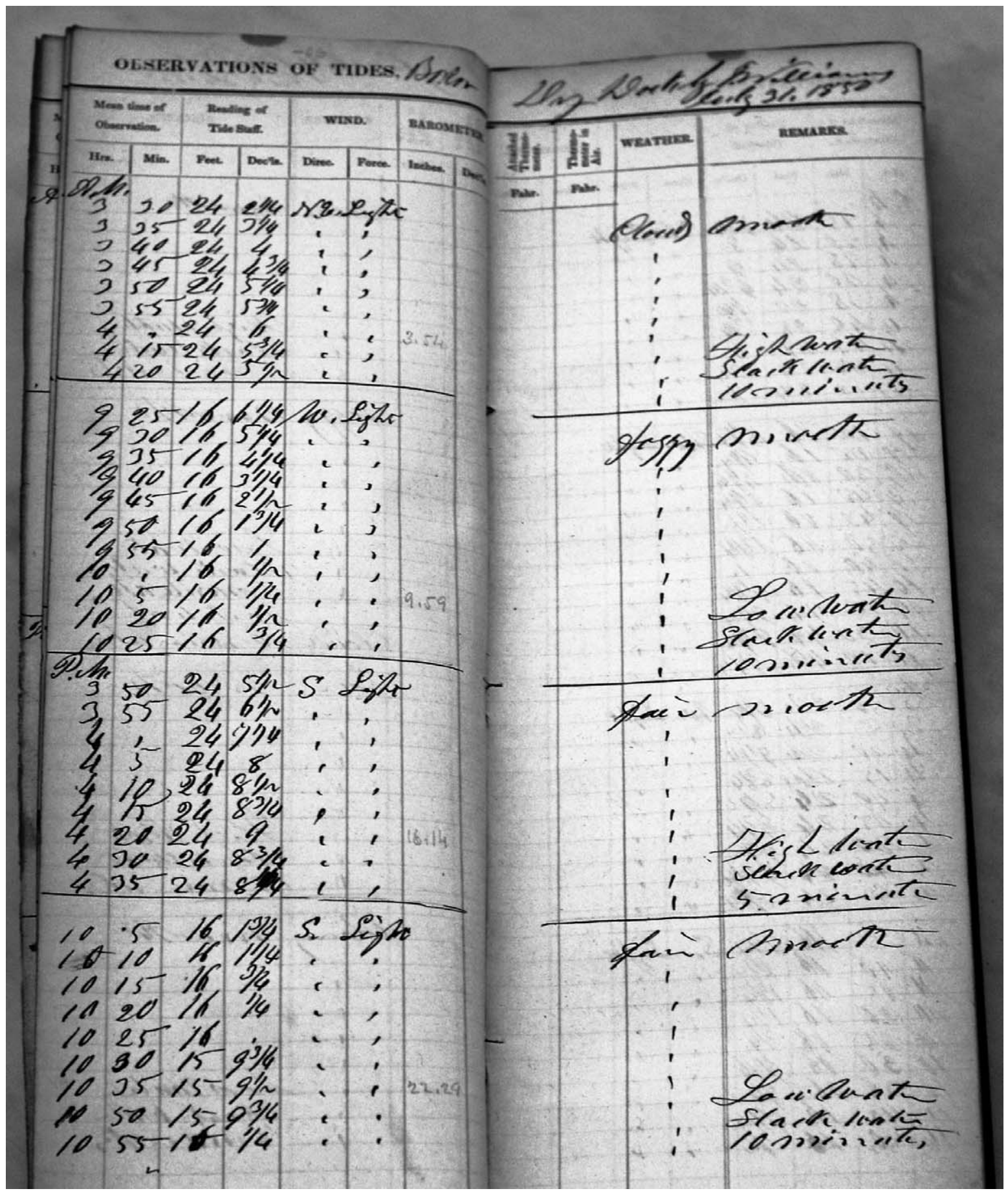

Figure 2. Example of manually measured tide data from Boston, Massachusetts, on 31 July 1850.

fluctuations (edge waves, seiching, etc.), tabulators (known as computers) sometimes interpolated the approximate time and height of high and low water (see Figure 4). Similarly, when the marigram data was missing, tabulators often interpolated data from high water/low water tabulations or from tide tables $(e . g$.
San Francisco in May 1862; see Figure 5) to complete hourly listings and monthly summaries. These examples illustrate the necessity of re-examining the original record for possible errors or bias, particularly for studies examining the nontidal (residual) portion of the historical record. 


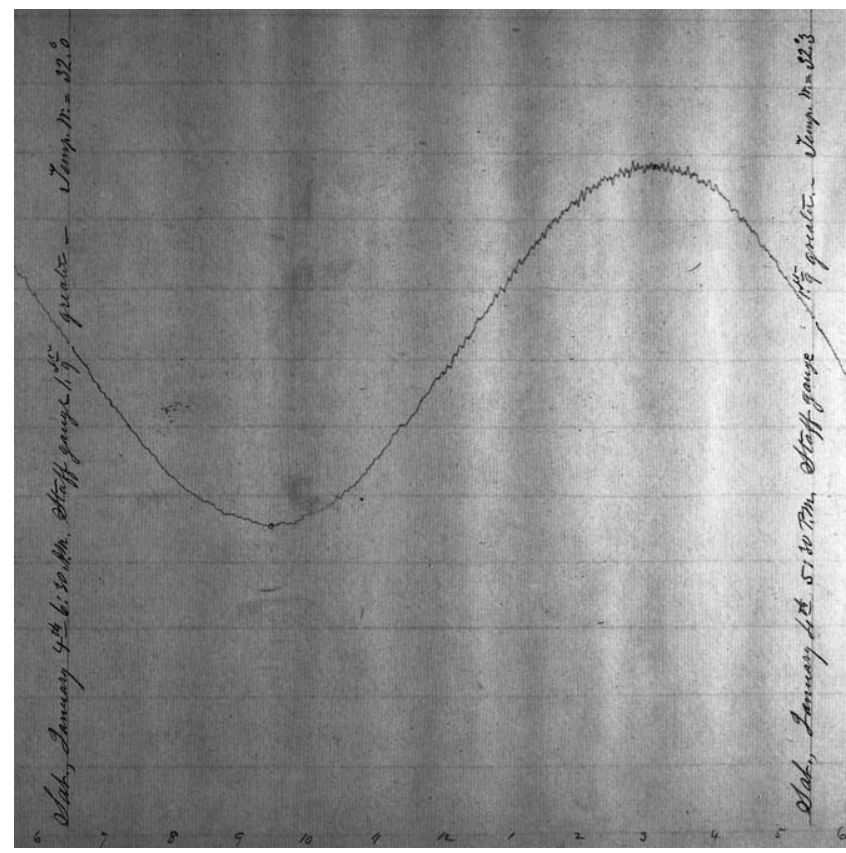

Figure 3. A marigram from a self-registering tide gauge in Astoria, Oregon, on 4 January 1862 . Each horizontal line represents approximately $30 \mathrm{~cm}$ of water level. Note the extremely cold water temperatures listed for the morning and afternoon gauge check and the infragravity oscillations on the rising tide and near high water.

With the development of harmonic analysis by William Thomson in 1867 (Thomson, 1868) and the advent of tidepredicting machines in 1872 in England (Thomson, 1881) and the early 1880s in the United States (Ferrel, 1882), year longtime series of hourly spaced data became necessary (Figure 5). Around this time, many (but not all) of the pre-1880 U.S. marigrams appear to have been reduced to hourly measurements. These data are stored by either NOAA or the U.S. National archives (e.g. Fort Point, California, 1854-77; San Diego, California, 1853-72; Astoria, Oregon, 1870-76; Governor's Island, New York, 1860-79; Boston, Massachusetts, 1869-77; Old Point Comfort, Virginia, 1865, 1874-78). The remaining data is typically available as tabulated high/low data.

\section{Ancillary Data}

To compare historical MSL with modern gauges and to assess data quality, benchmark information and ancillary data such as gauge and time checks are also required. As early as the 1850 s, it was standard practice for the U.S. Coastal Survey to tie tide gauges to at least one primary benchmark. The benchmark locations and elevation for 12 Atlantic and Gulf Coast gauges were described in the annual U.S. Coastal Survey Report (1854). Some early benchmarks (e.g. the Astoria 'tidal rock' benchmark from 1853) still exist (Figure 6) and can be resurveyed today, while the elevation of others must be recovered by examining later surveys. For U.S. west coast stations, we have recovered early benchmark data from NOAA

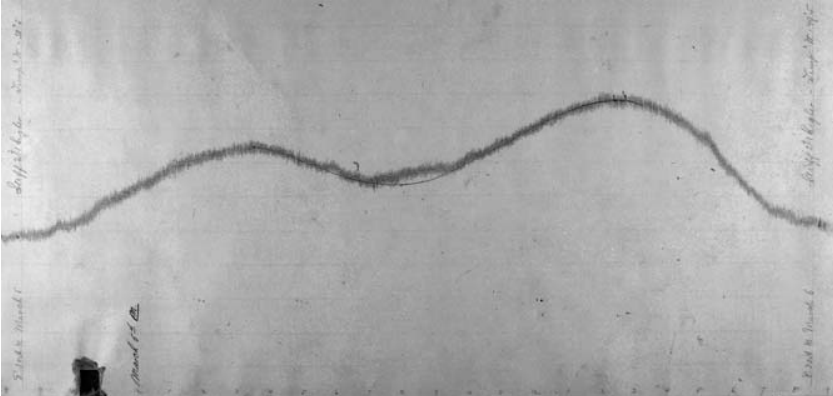

Figure 4. Marigram from 5 March 1862, from San Francisco, California. Nontidal fluctuations are evident and required interpolation by the tabulator to estimate the astronomical low water (see interpolation line and low-water point). The thick pencil line indicates atypical, short $(<1$ minute) fluctuations caused by a stilling well problem or by dock vibrations after moving the gauge to a new gauge house, which was necessitated by the severe storms of December 1861 to February 1862.

in the form of leveling surveys (e.g. Astoria, 1887; see Figure 5) or from data contained in hydrographic surveys and available in the U.S. National archives (San Diego, 1898; Kodiak Island, 1920). Multiple benchmarks were typically used in these later surveys and indicate growing sophistication in methods. These late 19th/early 20th century surveys can often be tied to present gauges using the data from periodic resurveys, many of which are cataloged by agencies such as NOAA. Historical publications also describe benchmarks and local datums, for example, in Australia (Ellery, 1880; Russell, 1890-1903) and Canada (Dawson, 1907). Hence, it is probable that other benchmarks from as early as the 1840 s can be recovered throughout the Pacific and North America, though local archival research in the country of origin is often required (e.g. Hunter, Coleman, and Pugh, 2003, in Tasmania).

Routine time and elevation checks are also vital to make recovered marigram data useful. For U.S. and Canadian data, ancillary data are stored with the tide tabulations and/or were marked on the original marigrams. For example, the gauge in Astoria, Oregon, was typically checked twice a day (morning and evening), and the difference between the gauge height and a tide staff was tabulated (Figure 3 ). These measurements were later used to scale the marigram to a tidal height by hand tabulators.

\section{Challenges}

A typical problem in many historic tide measurements was occasional sedimentation or clogging of the intake holes in the stilling well (e.g. San Francisco in Sept. 1904; see supplementary material). These problems often produce spurious data that contaminate modern tidal analyses (see, e.g. Moftakhari et al., 2013). Because time-keeping could also pose a problem, tide-gage keepers also checked their chronometers (clocks) and tabulated (on a monthly basis) the error, which was typically on the order of a few seconds a day but occasionally more (see supplementary material). Because the chronometer was checked at local high noon, most (if not all) of the early tide measurements appear to have been made in local mean city 


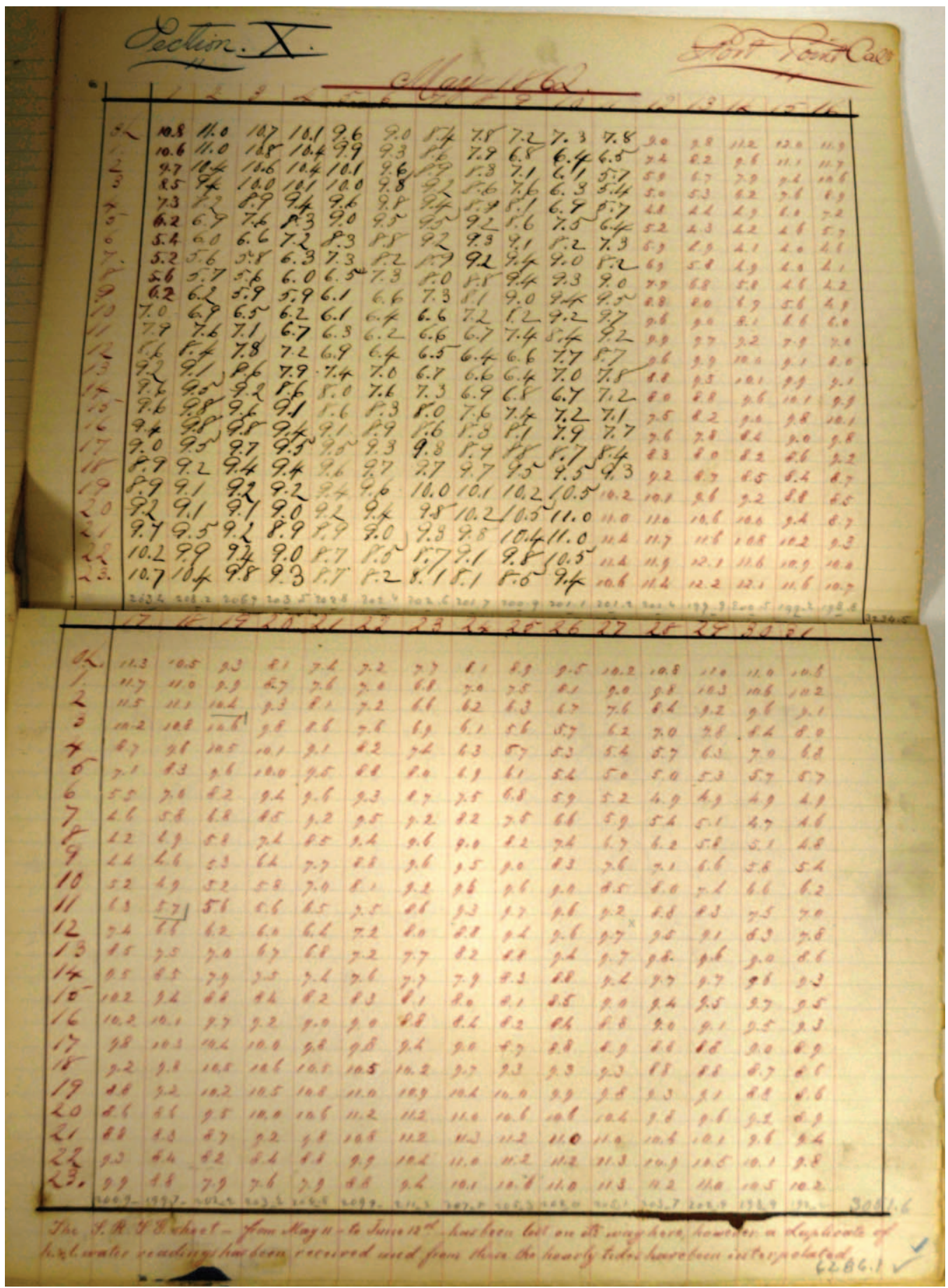

Figure 5. Example of a month of hourly tabulated data from San Francisco, California, from May 1862. Times are in the left column, while days are listed horizontally. Sums of the columns were used to check the veracity of the tabulation. Red (lighter colored) tabulations indicate interpolated (rather than actual) data, as explained in the note on the bottom: "The S.R.T.G. (Self Recording Tide Gage) Sheet from May 11 to June $12^{\text {th }}$ has been lost on its way here, however a duplicate of high water readings has been received and from this the hourly tides have been interpolated." (Color for this figure is available in the online version of this paper.) 


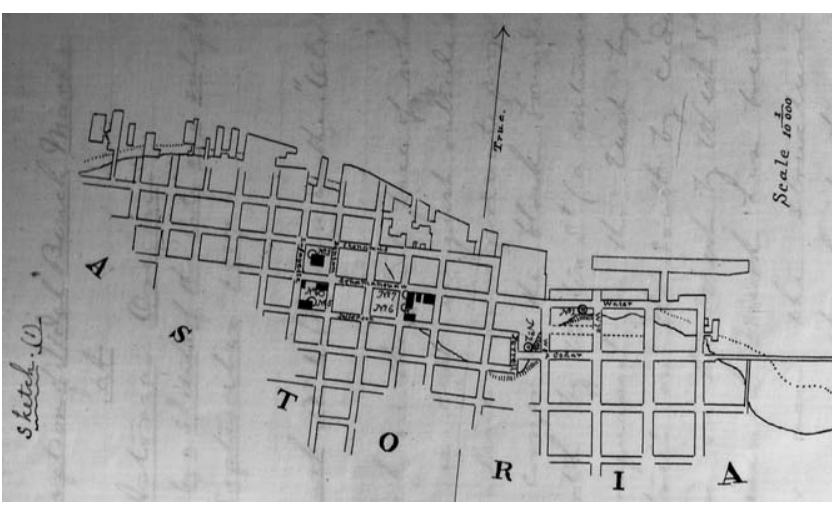

Figure 6. Locations of Astoria, Oregon, benchmarks 1-7 (marked in red) from an 1887 leveling survey by the U.S. Coastal Survey (data at U.S. national archives in College Park, Maryland). The No. 1 benchmark from 1853 still exists. The old shoreline (dotted line) indicates that infilling occurred between 1854 and 1887 .

time (standardized time zones did not become common in the United States until the mid-1880s).

Other problems may enter historical records; for example, the wharf in San Francisco subsided by approximately $0.75-0.9$ m between July 1854 and April 1858, according to a 19th century reanalysis of data (see supplementary material). Combined with problems with the tide gauge (silting), early San Francisco data from 1854-58 are of questionable utility (see also Bromirski, Flick, and Cayan, 2003). MSL estimates from $1876-81$ were also corrected by as much as $0.07 \mathrm{~m}(0.24 \mathrm{ft})$ because of tide staff instability (see supplementary material). It is worth noting, however, that most of the issues described previously continued to affect tide measurements for most of the 20th century and have been documented in some cases to bias MSL estimates (see, e.g. Agnew, 1986). The example of San Francisco suggests that even well established, long-term tidal data sets might benefit from a careful reanalysis of original meta-data to flag time periods with problems.

Because the 19th century observers lived at or near the tidegauge house, the marigram records from the 19th century might, in some cases, be superior (and/or more complete than) to 20th century measurements. For example, the tide-gauge observer in Astoria (Louis Wilson) checked the gauge between 50-60 times per month for nearly 20 years. By contrast, our archival research indicates that the San Francisco gauge between 1920-40 was checked only 10-15 times per month, and a similar practice seems to have been in place for west coast gauges in the 1960s and 1970s (Agnew, 1986).

\section{CONCLUSIONS}

A first step to spurring international recovery, use, and reanalysis of long-neglected, multiyear tide records from the 19th century is to document their history. Worldwide, early measurements were more widespread than modern compilations would suggest. The Ems estuary alone had multidecadal records from 24 locations by 1900 (Keller, 1901). Storm surge on the Elbe estuary using tide data from 1841-95 was described by Nehls (1896). Tide gauges were operating before 1900 in other European countries (e.g. Bouquet de la Gyre, 1901), along U.S. and Canadian coasts, and in colonies such as India, Pakistan, Singapore, Indonesia, and South Africa. Wharton (1888) documented 35 gauges (not including Figure 1c) at which the 1883 Krakatoa tsunami was observed. Therefore, a concerted international effort to document, locate (where possible), and digitize these data is needed (see also Woodworth, 2006). Continued efforts by GLOSS/IOC, the UHSLC, other government agencies, data archeology efforts such as http://ils.unc.edu/ janeg/dartg/, and scientists in various countries are slowly increasing the amount of digitized data (Caldwell, 2003; Hannah, 1990; Marcos et al., 2011; Watson, 2011) and might over time address the paucity of available 19th century data.

Across the Pacific basin and throughout North America, extensive, multidecade measurements of tides were made starting in the mid-19th century. At least 50 multiyear tidal data sets were collected by the year 1900, and at least 600 station years of tabulated data are currently unused and stored in national or local archives. Collectively, these data could help address important scientific questions such as secular trends in MSL, tidal range, and the hydrologic cycle and help assess anthropogenic impacts on estuarine dynamics. Because these data document historical tsunamis, storms, and floods, they might also spur reanalysis of extreme events such as the flood of 1862 on the U.S. west coast.

\section{ACKNOWLEDGMENTS}

We thank three anonymous reviewers for their helpful comments on the manuscript. Support for this project was provided in part by a Miller Foundation grant to the Institute of Sustainability and Systems at Portland State University and a Portland State research enhancement grant. The archival research described here was instigated by a U.S. National Science Foundation grant to investigate the Secular Changes in Pacific Tides, OCE-0929055, which provided support for S. A. Talke and D. A. Jay. In addition, S. A. Talke was supported in part by National Science Foundation grant OCE-1155610, 19th Century U.S. West Coast Sea Level and Tidal Properties.

\section{LITERATURE CITED}

AAAS (ANZAAS), 1913. Hall, T.S. (ed.), Proceedings of the Fourteenth Meeting of the Australasian Association for the Advancement of Science. Melbourne: AAS (ANZAAS), 751p.

Agnew, D.A., 1986. Detailed analysis of tide gauge history: a case analysis. Marine Geodesy, 10(3-4), 231-255.

Amin, M., 1983. On perturbations of harmonic constants in the Thames estuary. Geophysical Journal of the Royal Astronomical Society, 73(3), 587-603.

Bache, A.D., 1855. Preliminary determination of co-tidal lines on the Atlantic Coast of the United States, from the Coast Survey Tidal Observation. Proceedings of the American Association for the Advancement of Science, 8th meeting, Washington, D.C., J. Lovering (ed.), pp. 107-116.

Bouquet de la Gyre, M.D., 1901. Rapport sur les Marees, Verhandlungen, Dreizehnten Allgemeinen Conferenz der Internationalalen Erdmessung, Paris, van de Sande Bakhuyzen (eds.). Vol. VIII, Annexe B, pp. 122-138. 
Bromirski, P.D.; Flick, R.E.; and Cayan, D.R., 2003. Storminess variability along the California coast: 1858-2000. Journal of Climate, 16(6), 982-993.

Caldwell, P., 2003. NOAA support for global sea level data rescue. Earth System Monitor, 14(1), 1-6.

Chapman, R., 1938. The Tides of Australia. Official Year Book of the Commonwealth of Australia, No. 31, pp. 972-984.

Chernetsky, A.S.; Schuttelaars, H.M., and Talke, S.A., 2010. The effect of tidal asymmetry and temporal settling lag on sediment trapping in tidal estuaries. Ocean Dynamics, 60, 1219-1241.

Church, J.A. and White, N.J., 2011. Sea-level rise from the late 19th to the early 21st century. Surveys in Geophysics, 32(4-5), 585-602.

Colosi, J.A. and Munk, W., 2006. Tales of the venerable Honolulu tide gauge. Journal of Physical Oceanography, 6(36), 967-996.

Darwin, G.H., 1891. On tidal prediction. Philosophical Transactions Royal Society London, A182, 159-229.

Dawson, W.B., 1907. Tide levels and datum planes on the Pacific Coast of Canada. Transactions Canadian Society Civil Engineering, 20, Paper No. 250, 55-76.

Ellery, R.L.J., 1880. The Tidal Datum of Hobson's Bay. Transactions and Proceedings of the Royal Socety of Victoria, Vol. XVI, Melbourne, pp. 146-148.

Ferrel, W., 1882. Discussion of the tides of the Pacific Coast of the United States, Annual Report of the Coast and Geodetic Survey, Appendix 17, Washington, D.C., pp. 437-450.

Freeman, J.R., 1903. Committee on Charles River Dam; Report of the Committee on Charles River Dam, appointed under resolves of 1901, chapter 105, to consider the advisability and feasibility of building a dam across the Charles River at or near Craigie bridge. Boston: Wright and Potter.

Hannah, J., 1990. Analysis of mean sea level data from New Zealand for the period 1899-1988. Journal of Geophysical Research, 95(B8), $12399-12405$.

Hirayama, S., 1911. Results of the harmonic analysis of tidal observations made at various ports of Japan. Journal of the College of Science, Imperial University, Tokyo, Vol XXVIII, Article 7, pp. 165.

Houston, J.R. and Dean, R.G., 2011. Sea-level acceleration based on U.S. tide gauges and extensions of previous global-gauge analyses. Journal of Coastal Research, 27(3), 409-417.

Hunter, J.; Coleman, R., and Pugh, D., 2003. The sea level at Port Arthur, Tasmania, from 1841 to the present. Geophysical Research Letters, 30(7), 1401. doi: 10.1029/2002GL016813.

International Hydrographic Review (IHR), 1932. Vol. 9. Monaco: International Hydrographic Bureau, p.74.

Jay, D.A., 2009. Evolution of tidal amplitudes in the eastern Pacific Ocean. Geophysical Research Letters, 36, L04603. doi: 10.1029/ 2008GL036815.

Jay, D.A. and Kukulka, T. 2003. Revising the paradigm of tidal analysis-the uses of non-stationary data. Ocean Dynamics, 53, 110-123.

Jevrejeva, S.; Grinsted, A.; Moore, J.C., and Holgate, S., 2006. Nonlinear trends and multiyear cycles in sea level records. Journal of Geophysical Research, 111, C09012. doi: 10.1029/2005JC003229.

Keller, H., 1901. Weser and Ems, ihre Stromgebiete und ihre wichtigsten Nebenfluesse: Eine hydrographische, wasserwirtschaftlichte und wasserrechtliche Darstellung. Vol. IV, Berlin: Dietrich Reimer, 575p.

Komar, P.D.; Allan, J.C., and Ruggiero, P., 2011. Sea level variations along the U.S. Pacific Northwest Coast: tectonic and climate controls. Journal of Coastal Research, 27(5), 808-823.

Kukulka, T. and Jay, D.A., 2003. Impacts of Columbia River discharge on salmonid habitat I. A non-stationary fluvial tide model. Journal of Geophysical Research, 108(C9), 3293. doi: 10. 1029/2002JC001382.

Lander, J.F.; Lockridge, P.A., and Kozuch, M.J., 1993. Tsunamis affecting the west coast of the United States, 1806-1992. Boulder, CO: National Geophysical Data Center (NGDC), Key to Geophysical Records Documentation No. 29, 242p.

Levitus, S.; Sato, S.; Maillard, C.; Mikhailov, N.; Caldwell, P., and Dooley, H., 2005. Building Ocean Profile-Plankton Databases for
Climate and Ecosystem Research, NOAA Technical Report NESDIS 117, U.S. Gov. Printing Office, Wash., D.C., 29p.

Marcos, M.; Puyol, B.; Wöppelmann, G.; Herrero, C., and GarcíaFernández, M.J., 2011. The long sea level record at Cadiz (southern Spain) from 1880-2009. Journal of Geophysical Research, 116, C12003, 1-10. doi:10.1029/2011JC007558.

Matthäus, W., 1972. On the history of recording tide gauges. Proceedings Royal Society Edinburgh, Section B, 73(3), 25-34.

Maul, G.A. and Martin, D.M., 1993. Sea level rise at Key West Florida, 1846-1992: America's longest instrument record? Geophysical Research Letters, 20(18), 1955-1958.

Moftakhari, H.R.; Jay, D.A.; Talke, S.A.; Kukulka, T., and Bromirski, P.D., 2013. A novel approach to flow estimation in tidal rivers. Water Resources Research. doi: 10.1002/wrcr.20363.

Nehls, C., 1896. Die Sturmfluthen in der Elbe, insbesondere die Sturmfluthen vom 12. Februar und vom 22. /13. December 1894, sowie vom 5. bis 8- December 1895. Hydrologischer Jahresbericht von der Elbe für 1895. Magdeburg, 30p.

Powell, C.F., 1884. Report of Mr. J.S. Polhemus, Assistant Engineer. Annual Report of the Chief of Engineers, U.S. Army, Appendix QQ13, Washington, D.C.: Government Printing Office, 2406p.

Proudman, J., 1920. Harmonic Analysis of Tidal Observations in the British Empire. British Association for the Advancement of Science, Report published by Association, Burlington House, W.1, 1921, pp. 321-345.

Rahmstorf, S. and Vermeer, M., 2011. Discussion of Houston, J.R. and Dean, R.G., 2011. Sea-level acceleration based on U.S. tide gauges and extensions of previous global-gauge analyses. Journal of Coastal Research, 27(3), 409-417.

Reidy, M.S., 2008. Tides of History: Ocean Science and Her Majesty's Navy. Chicago, Illinois: University of Chicago Press, 392p.

Richardson, G.F., 1901. Art. LXI-Survey: practical and precise. Transactions and Proceedings of the New Zealand Institute, 33, 492-499.

Roden, G.I., 1966. Low frequency sea level oscillations along the Pacific Coast of North America. Journal of Geophysical Research, 71(20), 4755-4776.

Russell, H.C., 1885. Anniversary address. Journal and Proceedings of the Royal Society of New South Wales, 1886, 19, 1-28.

Russell, H.C., 1890-1903. Results of Rain, River, and Evaporation Observations made in New South Wales. Published annually by the Government of New South Wales. Sydney: Gullick.

Schureman, P., 1934. Tides and Currents in Hudson River. U.S. Department of Commerce, Coast and Geodetic Survey Special Publication No. 180. Washington, D.C.: United States Government Printing Office, $107 \mathrm{p}$.

Smith, B.W., 1997. Meteorlogical and tide stations, 1890-1917. The Coast Defense Study Group Journal, Feb. 1997, 23-36.

Talke, S.A.; De Swart, H.E., and de Jonge, V.N., 2009. An idealized model and systematic process study of oxygen depletion in highly turbid estuaries. Estuaries and Coasts, 32, 602-620.

Thomson, W., 1868. Report of Committee for the purpose of promoting the extension, improvement, and harmonic analysis of tidal observations. British Association for the Advancement of Science, pp. 489-505.

Thomson, W., 1881. The tide gauge, tidal harmonic analyser, and tide predictor. Proceedings of the Institution of Civil Engineers, 65, 324.

United States Army Corps of Engineers (USACE), 1881-1915 Annual Report of the Chief of Engineers, U.S. Army, to Secretary of War. Washington, D.C.: Government Printing Office.

United States Coast and Geodetic Survey, 1877-1910 (published annually). Report of the Superintendent of the United States Coast and Geodetic Survey Showing the Progress of the Work for the Fiscal Year. Washington, D.C.: Government Printing Office.

United States Coastal Survey, 1854. Report of the Superintendent of the United States Coast Survey Showing the Progress of the Work for the Fiscal Year. Table 12, Appendix 5-List of benchmarks. Washington, D.C.: Government Printing Office.

United States Coastal Survey, 1854-1876 (published annually). Report of the Superintendent of the United States Coast Survey 
Showing the Progress of the Work for the Fiscal Year. Washington, D.C.: Washington Government Printing Office.

United States Hydrographic Office (USHO), 1920. New Zealand Pilot. Washington, D.C.: Government Printing Office, 446p.

Watson, P.J., 2011. Is there evidence yet of acceleration in mean sea level rise around mainland Australia? Journal of Coastal Research, 27(2), 368-377.

Wharton, W.J.L., 1888. On the Seismic Sea Waves Caused by the Eruption of Krakatoa, August $26^{\text {th }}$ and $27^{\text {th }}, 1883$. The Eruption of Krakatoa, and subsequent phenomena, Report of the Krakatoa committee of the Royal Society, G. J. Symons, F.R.S. (ed.), part III, pp. 89-151.

Wilson, R., 1938. Official Yearbook of the Commonwealth of Australia. Commonwealth Bureau of Census and Statistics, No. 31, p. 984. Canberra: L.F. Johnston, Commonwealth Government Printer.
Wood, S.H. and Elliot, M.R., 1979. Early $20^{\text {th }}$-century uplift of the northern penisular ranges province of southern California. Tectonophysics, 52, 249-265.

Woodworth, P.L., 2006. Some important issues to do with long-term sea level change. Philosophical Transactions of the Royal Society A, 364, 787-803.

Woodworth, P.L., 2010. A survey of recent changes to the main components of the ocean tide. Continental Shelf Research, 30(15), $1680-1691$.

Woodworth, P.L. and Blackman, D.L., 2002. Changes in extreme high waters at Liverpool since 1768. International Journal of Climatology, 22, 697-714.

Wright, T., 1902. Harmonic tidal constituents for certain Australian and Chinese ports. Proceedings Royal Society London, 1903, Vol. LXXI(468), 91-96. 